\title{
Do Performance Appraisal, Compensation Andjob Satisfaction Influence Employees' Loyalty Of Generation Y?
}

\author{
Neela Osman \\ Master of Management Program, Faculty of Economics, Universitas Negeri Jakarta \\ neelaosman@gmail.com
}

\section{Dedi Purwana}

Faculty of Economics, Universitas Negeri Jakarta dpurwana @unj.ac.id

\section{Ari Saptono}

Faculty of Economics, Universitas Negeri Jakarta saptono.fe@gmail.com

\begin{abstract}
GenerationY is the work force of the future and now the number is dominating the industry. The increasing number of employees of generation $Y$ becomes a separate problem for the company in meeting the availability of young professional workforce. The research aims to investigate effect of performance appraisal, compensation and job satisfaction to loyalty of generation Y.Method used in this study was quantitative. The research sample was 117 students. Data was anaysed using Structural Equation Modeling (SEM). This study reveals there are a positive relationship between performance appraisal with job satisfaction, compensation with job satisfaction and job satisfaction on loyalty.
\end{abstract}

Keywords: Performance appraisal, Compensation, Job satisfaction,Loyalty, and generation Y

\section{INTRODUCTION}

The future direction of companies in Indonesia in the next few years will be in the hands of generation Y, also known as millennial generation. By the year 2020 (next three years), this generation will dominate the industry with the number of productive age population reaches 70 percent of the total population, with an estimated population of about 262 million (BPS 2013). The dominance of productive age or also known as demographic bonus (2020) can be a double-edged knife. If managed properly, demographic bonuses can bring Indonesia into a brilliant future.

Conversely, demographic bonuses can also turn into a demographic disaster. Especially if the millennia generation is not properly managed. The number of millennials in Indonesia has reached 84 million people (data BPS 2015) or 50 percent of the productive age population.

Behind the potential of human resources owned, companies in Indonesia face the challenge to be able to manage human resources, especially generation Y. According to Antonius (Chief Product Officer Jobplanet), millennial generation or Y generation has a negative stigma attached "prominent is free to choose a job and choose the business run, and often move the job". This is evidenced by the results of the Jobplanet research related to generation $\mathrm{Y}$ in the period August 2015 to January 2017, the results reinforce the stigma that the Y generation totals over 90 thousand respondents, opting out after working one and two years.

A study conducted by PwC (2011) through an online survey of 4,364 graduates in 75 countries revealed that $38 \%$ of millennia currently working say they are actively seeking different roles and $43 \%$ say they are open to offer. Only $18 \%$ are looking forward to staying with their current 
company for the long term. GenerationY or millennials look for new opportunities, even if they are not actively looking for new jobs.

Y generations' unfaithfulness are also revealed by some of an earlier research by Queiri et al. (2015), which explains why Y-generation workers often change jobs, and finding work-life balance to be their goals, the survey shows that Y's employees have the shortest working life compared to the generation $\mathrm{X}$ workforce and baby boomers. According to Howe and Strauss (1991) Y generation (born 1980-1994), the current presumption of Y genes is lacking in high commitment and loyalty in the workplace. According to research by Othman and Lembang (2017), shows that compensation can encourage employees' commitment to the organization, increase productivity and employees are willing to remain in the organization. In addition, effective performance appraisal and planning systems contribute to employee fairness perceptions and this greatly affects employees. Employees who feel treated fairly by their employers are more likely to stay on their jobs than those who do not. So performance appraisal can not only improve employee performance but also influence employees' intention to stay in organization. However, other research results from Queiri et al. (2015), says that there is no relation between earned income and job satisfaction with the desire of generation $\mathrm{Y}$ to survive in the organization. According to research Waqas et al. (2014) says there is a very strong relationship of giving fair compensation and in accordance with the desired employee in forming job satisfaction and from job satisfaction that created results with a relationship that is also large in the form of work loyalty. While research from Ibrahim et al. (2016), there is a substantial effect of providing compensation to employees 'willingness to stay and loyal to the organization, while performance appraisals do not have an impact on employees' willingness to stay with the organization they work for.Departing from the above, in this study, the authors will test the influence of performance appraisal factors and compensation in creating job satisfaction to further create the work loyalty of generation Y.

\section{LITERATURE REVIEW Loyalty}

Generation Y employees' loyalty tends to remain if the value of the firm matches their value (Deal, 2007). For example, how companies deal with organizational change and manage it and whether the organization will create opportunities for better quality of life, better communications, and improvements such as more specific jobs. Generation $\mathrm{Y}$ is also likely to stick with the organization if the organization respects young people, at least for their expertise. Smola and Sutton (2002) also argue that Y-generation employees are more self-oriented. They want to be promoted quicker than older workers, tend to feel that work should be an important part of their lives and have a higher intention to quit their jobs if they get a bid for a greater amount of rewards elsewhere. According to Waqas et al. (2014) loyalty is the employee's loyalty to his organization, when he demonstrates his commitment and believes that it is the best option for him to work for the organization. McCrindle (2006) argues that if the Y generation is in a new workplace and see that they will get a lot of lessons, there is a chance they will survive, and loyalty is also about lifestyle changes.

\section{Job Satisfaction}

Job satisfaction is an employee attitude towards work related to work situation, cooperation between employees, rewards received in work, and matters concerning physical and psychological factors (Sutrisno, 2014: 74). Another opinion, job satisfaction is as an individual's general attitude towards his work, also explained that a person with high job satisfaction shows a positive attitude towards the job, otherwise someone who is not satisfied with his work shows a negative attitude towards the job (Robbins \& Judge, 2009: 105).Furthermore, job satisfaction is essentially something that is individual, each individual has a different level of satisfaction in accordance with the system of prevailing values (Rivai\&Sagala, 2013: 856). Another opinion about job satisfaction is that those who are satisfied with their work will be more productive, creative and committed to companies where organizations with more satisfied employees tend to be more effective than organizations with fewer satisfied employees (McShane \&Glinow, 2009: 108). Many factors affect employee job satisfaction. The factors themselves in the role of giving satisfaction to employees depend on the personalities of each employee. The factors that give satisfaction according to Sutrisno (2014: 77) are:a) Individual factors; including age, health, character, and hope; b) Social 
factors; including familial relations, employment views, political freedom, and community relations; and c) The main factor in the work; including wages, supervision, work tranquility, work conditions and opportunities to move forward.

According to Robbins and Judge (2009: 106), there are 5 factors that affect job satisfaction; which are a) Satisfaction with the job itself, this satisfaction is achieved when an employee's work is consistent with his or her interests and abilities; b) Satisfaction with the rewards of the job,where the employee feels the salary or wages he received is in accordance with his workload and balanced with other employees working in the organization; c) Satisfaction with supervision from superiors, when employees feel they have a boss who is able to provide technical assistance and motivation; d. Satisfaction with co-workers, when employees are satisfied with their colleagues who are able to provide technical assistance and social encouragement; and e) Promotional opportunities, the opportunity to improve the position of the position on the organizational structure.

\section{Performance Appraisal}

Performance appraisal is a system used to assess and know whether an employee has performed his or her overall work (Sedarmayanti, 2015: 260). Performance appraisal means evaluating the performance of current and past employees relative to its performance standards, assuming that employees understand what their performance standards are, and the supervisor also gives employees the necessary feedback, development, and incentives to continue their good performance (Dessler, 2013: 284).

Performance appraisal is the process by which the organization evaluates employee performance, this activity can improve personnel decisions and provide feedback to employees about their work (Handoko, 2014: 135). According to Rivai and Sagala (2013: 549) the main purpose of performance appraisal is to motivate individual employees to achieve organizational goals and in meeting predetermined standards of behavior, resulting in actions and results desired by the organization.

Some of the assumptions underlying the importance of performance appraisal by Sedarmayanti (2015: 265) are a) Everyone wants to have the opportunity to develop their work ability as much as possible; b) Everyone wants to be rewarded when he or she is judged to be doing a good job; c) Everyone wants to know what career they will achieve when they do their job well; and d) Everyone wants to get objective treatment and judgment based on performance.

\section{Compensation}

Compensation is all income in the form of money, goods directly or indirectly received by employees in return for services rendered to the company (Hasibuan, 2014: 118). Compensation is important to employees as individuals because the amount of compensation reflects the size of the value of their work among the employees themselves, their families and society (Handoko, 2014: 155). According to Dessler (2013: 352) employee compensation is any form of payment or compensation paid to employees and arises from the employee's employment.

Sedarmayanti (2015: 239) states that the objectives of the management of the compensation system are:
a. Appreciate performance.
b. Ensure justice.
c. Retain employees.
d. Get qualified employees.
e. Controlling costs.
f. Meet the rules. 


\section{RESEARCH METHOD}

This research uses quantitative approach. Based on data collection techniques, this study uses primary data. Primary data was obtained through questionnaires.

In this study, the target population is students at the Master of Management Study Program Faculty of Economics, Universitas Negeri Jakarta. The size of the sample is adjusted to the analysis model used is structural equation modeling (SEM). The number of respondents were 117 students. Sampling is done by using probability sampling method, ie students who meet the criteria to be selected as research sample. In this study, the variables are performance appraisal, compensation, job satisfaction and employee loyalty. The measurement of variables will be based on the indicators. This research used Likert scale measurement, where the answer of available statement ranges from number 1 to number 5 . The research model can be seen in figure 1 .

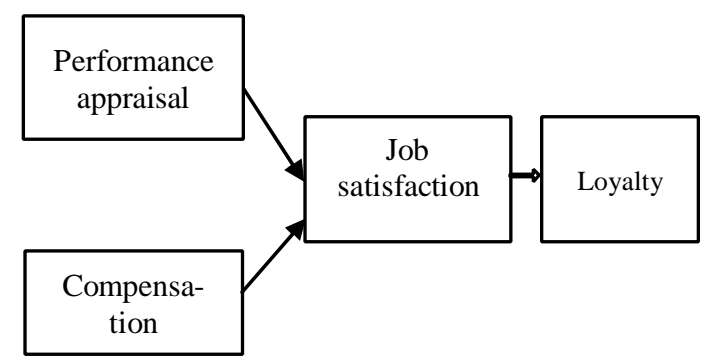

Figure 1. Conceptual framework

The hypotheses formulated in this study are:

$\mathbf{H}_{\mathbf{1}}$ : Performance appraisal affectsjob satisfaction.

$\mathbf{H}_{2}$ : Compensationaffects job satisfaction.

$\mathbf{H}_{3}$ : Job satisfaction affectsemployee loyalty.

$\mathbf{H}_{\mathbf{4}}$ : Performance appraisal affects loyalty through job satisfaction.

H5: Compensationaffects loyalty through job satisfaction.

\section{RESULT AND DISCUSSION}

This research used Structural Equation Modeling (SEM) analysis. The software used for this research is SPSS AMOS 21. The theoretical model that has been described in the path diagram will be analyzed based on the data obtained.

\section{Full Model Analysis-Structural Equation Model}

Analysis of data processing result at full stage of SEM model is done by applying conformity test and statistical test. Results of data processing for the analysis of full SEM model shown in Figure 2 . 


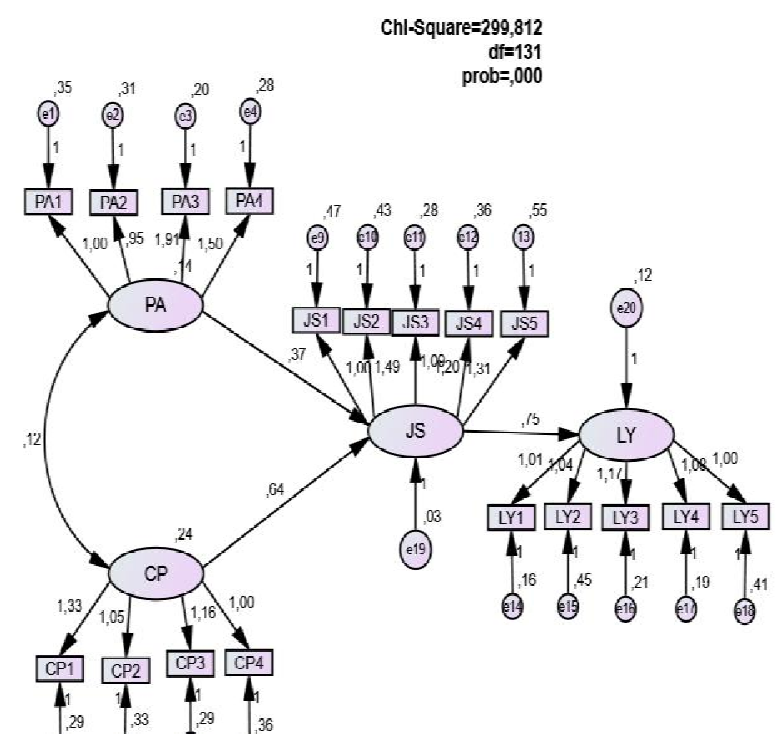

Figure 2.

Full Model-Structural Equation Model (SEM)

Caption:

PA (performance appraisal)

CP (compensation)

JS (job satisfaction)

LY (loyalty)

\section{Confirmatory Factor Analysis}

The measurement model with Confirmatory factor analysis (CFA) is an analysis that aims to identify the relationship between variables with indicators and perform correlation test to confirm whether the measurement model built in accordance with the hypothesized. (Haryono \&Wardoyo, 2013: 106). CFA processing is done with AMOS 21 software. Here is the test result based on the data obtained.

Table 1. Standardized Loading Factor

\begin{tabular}{|c|c|c|c|}
\hline No & Indicator & Standardized Loading Factor & Information \\
\hline 1 & PA1 & 0,531 & Valid \\
\hline 2 & PA2 & 0,537 & Valid \\
\hline 3 & PA3 & 0,846 & Valid \\
\hline 4 & PA4 & 0,722 & Valid \\
\hline 5 & CP1 & 0,770 & Valid \\
\hline 6 & CP2 & 0,668 & Valid \\
\hline 7 & CP3 & 0,726 & Valid \\
\hline 8 & CP4 & 0,630 & Valid \\
\hline 9 & JS1 & 0,549 & Valid \\
\hline
\end{tabular}




\begin{tabular}{|c|c|c|c|}
\hline 10 & JS2 & 0,717 & Valid \\
\hline 11 & JS3 & 0,677 & Valid \\
\hline 12 & JS4 & 0,670 & Valid \\
\hline 13 & JS5 & 0,624 & Valid \\
\hline 14 & LY1 & 0,767 & Valid \\
\hline 15 & LY2 & 0,599 & Valid \\
\hline 16 & LY3 & 0,775 & Valid \\
\hline 17 & LY4 & 0,767 & Valid \\
\hline 18 & LY5 & 0,603 & Valid \\
\hline
\end{tabular}

Based on table 1,it can be seen that allstandarized loading factor value $\geq 0,5$. Therefore it can be deduced that all indicators of each variable are valid. Furthermore, it can be concluded that all indicators can be used for the calculation in the next stage.

\section{Test of Goodness of Fit Model}

The test results of goodness of fit model are described in table 2 .

Table 2. Test Result of Goodness of Fit Model

\begin{tabular}{|c|c|c|c|}
\hline Size (GOF) & Match Target & $\begin{array}{c}\text { The Calculation } \\
\text { Results }\end{array}$ & Match Rate \\
\hline $\begin{array}{c}\text { Statistic ChiSquare } \\
\left(\mathrm{X}^{2}\right)\end{array}$ & Small value 169,33 & 299,812 & Poor fit \\
\hline $\mathrm{P}$ & $\mathrm{P} \leq 0,05$ & $\mathrm{P}=0,000$ & \\
\hline \multirow[t]{3}{*}{ GFI } & $\mathrm{GFI} \geq 0,90$ & \multirow[t]{3}{*}{0,781} & \multirow[t]{3}{*}{ Marginal fit } \\
\hline & $0,80 \leq \mathrm{GFI}<0,90$ & & \\
\hline & $\mathrm{GFI} \leq 0,80$ & & \\
\hline \multirow[t]{3}{*}{ RMSEA } & RMSEA $\leq 0,08$ & \multirow[t]{3}{*}{0,105} & \multirow[t]{3}{*}{ Marginal fit } \\
\hline & $0,08 \leq \mathrm{RMSEA}<0,10$ & & \\
\hline & RMSEA $\geq 0,10$ & & \\
\hline \multirow[t]{3}{*}{ TLI } & $\mathrm{TLI} \geq 0,90$ & \multirow[t]{3}{*}{0,785} & \multirow[t]{3}{*}{ Marginal fit } \\
\hline & $0,80 \leq \mathrm{TLI}<0,90$ & & \\
\hline & $\mathrm{TLI} \leq 0,80$ & & \\
\hline \multirow[t]{3}{*}{ IFI } & $\mathrm{IFI} \geq 0,90$ & \multirow[t]{3}{*}{0,820} & \multirow[t]{3}{*}{ Marginal fit } \\
\hline & $0,80 \leq \mathrm{IFI}<0,90$ & & \\
\hline & $\mathrm{IFI} \leq 0,80$ & & \\
\hline $\mathrm{CFI}$ & $\mathrm{CFI} \geq 0,90$ & 0,90 & Good Fit \\
\hline
\end{tabular}




\begin{tabular}{|c|c|c|c|}
\hline \multirow{2}{*}{ Norm Chi-Square } & \multicolumn{1}{c|}{} & \\
\cline { 2 - 3 } & $\begin{array}{c}0,80 \leq \mathrm{CFI}<0,90 \\
\mathrm{C} \text { CFI } \leq 0,80 \\
\mathrm{CMIN} / \mathrm{DF} \leq 5\end{array}$ & Marginal fit \\
\hline PNFI & PNFI $\square 0,50$ & 2,288 & Good Fit \\
\hline PCFI & PCFI $\square 0,50$ & 0,598 & Good Fit \\
\hline
\end{tabular}

These results indicate that the model used is acceptable, with a good fit CFI value. Although some criteria are slightly beyond the recommended value or marginal fit.

However, the size of the other fit parsimony shows that the results is fit. The value of PNFI = 0.598 and PCFI $=0.767$ is above 0.50 indicating that this model is received at the fit level.

\section{Normality Test}

Normality test data is done by using the value ratio of critical skewness and kurtosis value of \pm 2.58 . The data is said to be normal distribution if the value of ratio of critical skewness and kurtosis value under \pm 2.58 (Santoso, 2015: 81).

Table 3. Assessment of normality

\begin{tabular}{|l|l|l|l|l|l|l|}
\hline \multicolumn{1}{|c|}{ Vrbl } & \multicolumn{1}{|c|}{$\min$} & \multicolumn{1}{c|}{ Max } & \multicolumn{1}{c|}{ skw } & \multicolumn{1}{c|}{ c.r. } & \multicolumn{1}{c|}{ kurts } & \multicolumn{1}{c|}{ c.r. } \\
\hline LY1 & 3,0 & 5,00 &,- 124 &,- 548 &,- 559 & $-1,234$ \\
\hline LY2 & 2,0 & 5,00 &,- 415 & $-1,832$ &,- 320 &,- 708 \\
\hline LY3 & 2,0 & 5,00 &,- 292 & $-1,290$ &,- 355 &,- 785 \\
\hline LY4 & 3,0 & 5,00 &, 042 &, 185 &,- 829 & $-1,831$ \\
\hline LY5 & 1,0 & 5,00 &,- 440 & $-1,942$ &, 377 &, 831 \\
\hline JS5 & 2,0 & 5,00 &,- 015 &,- 064 &,- 918 & $-2,026$ \\
\hline JS4 & 2,0 & 5,00 &,- 400 & $-1,765$ &,- 660 & $-1,458$ \\
\hline JS3 & 2,0 & 5,00 &,- 144 &,- 636 &,- 246 &,- 544 \\
\hline JS2 & 1,0 & 5,00 &,- 350 & $-1,544$ &,- 216 &,- 478 \\
\hline JS1 & 2,0 & 5,00 &,- 364 & $-1,607$ &,- 349 &,- 770 \\
\hline CP1 & 2,0 & 5,00 &,- 195 &,- 859 &,- 545 & $-1,204$ \\
\hline CP2 & 2,0 & 5,00 &,- 192 &,- 850 &,- 312 &,- 689 \\
\hline CP3 & 2,0 & 5,00 &, 069 &, 303 &,- 519 & $-1,146$ \\
\hline CP4 & 2,0 & 5,00 &, 057 &, 251 &,- 453 & $-1,001$ \\
\hline PA4 & 2,0 & 5,00 &,- 363 & $-1,603$ &,- 198 &,- 438 \\
\hline PA3 & 2,0 & 5,00 &,- 387 & $-1,711$ &,- 356 &,- 786 \\
\hline PA2 & 2,0 & 5,00 &,- 252 & $-1,111$ &, 118 &, 259 \\
\hline PA1 & 2,0 & 5,00 &,- 102 &,- 450 &,- 197 &,- 434 \\
\hline Mltvr & & & & & 32,660 & 6,583 \\
\hline
\end{tabular}


From the table 3 above, it can be concluded that based on the test of normality the multivariate is not normally distributed. The results of the calculations shown in table 3 indicates that all the indicator values of critical ratio skewness and kurtosis value is below \pm 2.58 . It can be said data is univariate normal distribution and feasible to use.

\section{Outlier Data Evaluation}

Evaluation of outliers according to Santoso (2015: 73), is done to observe the observational conditions of a data having unique characteristics that look very different from other observations and appear in extreme form, whether for a single variable or combination variables. Outlier detection is done by looking at the value of mahalanobis distance. The result of outlier evaluation can be seen in table 4 .

Table 4. Testing of multivariate outliers

\begin{tabular}{|c|c|c|c|}
\hline $\begin{array}{r}\text { Observation } \\
\text { number }\end{array}$ & Mahalanobis d-squared & $\mathrm{p} 1$ & $\mathrm{p} 2$ \\
\hline 11 & 37,293 & ,005 &, 430 \\
\hline 43 & 37,219 & 005 &, 113 \\
\hline 101 & 36,866 & ,005 &, 027 \\
\hline 67 & 33,842 & 013 & ,070 \\
\hline 62 & 33,417 & ,015 & 031 \\
\hline & & ${ }^{\circ}$ & $\cdot$ \\
\hline & & & . \\
\hline & & & 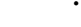 \\
\hline 27 & 11,084 & ,891 & ,996 \\
\hline 36 & 10,894 & ,899 & ,997 \\
\hline 55 & 10,493 & ,915 & ,999 \\
\hline 17 & 10,325 & ,921 & ,999 \\
\hline 74 & 10,250 & ,923 & ,999 \\
\hline 106 & 10,250 & ,923 & ,997 \\
\hline
\end{tabular}

The distance of mahalanobis for each observation will show the distance of an observation data to the average value (centroid) it. Observation of data that is far from its centroid value is considered outlier and must be discarded (in drop) from the analysis (Haryono\&Wardoyo, 2013: 309). The criteria used are based on the value of chi-squares on degrees of freedom (degree of freedom) 18 that is the number of indicators in the fit model of this study at the level of significance $\mathrm{p}<0.001$. Mahalanobis distance or X2 $(18 ; 0.001)=42.312$. This means all cases(observation number) which has a dalanquant value of d-squared greater than 42.312 is multivariate outliers. The results of the calculation of mahalanobis distance calculation shown in table 4 above it can be seen that all data observations have dalanquant value d-squared under 42,312 which means that the research data used has met the requirements there are no multivariate outliers. According to Santoso (2015: 82) no matter how biased a data remains a fact that must be taken into account as a finding. Because in behavioral research using ordinal scale, normality testing should not be necessary, because naturally, ordinal data is not quantitative data that must 
meet the assumption of normality. Yet another requirement requires SEM assumption is the fulfillment of normality test. The following will be tested for normality by using bootstrap.

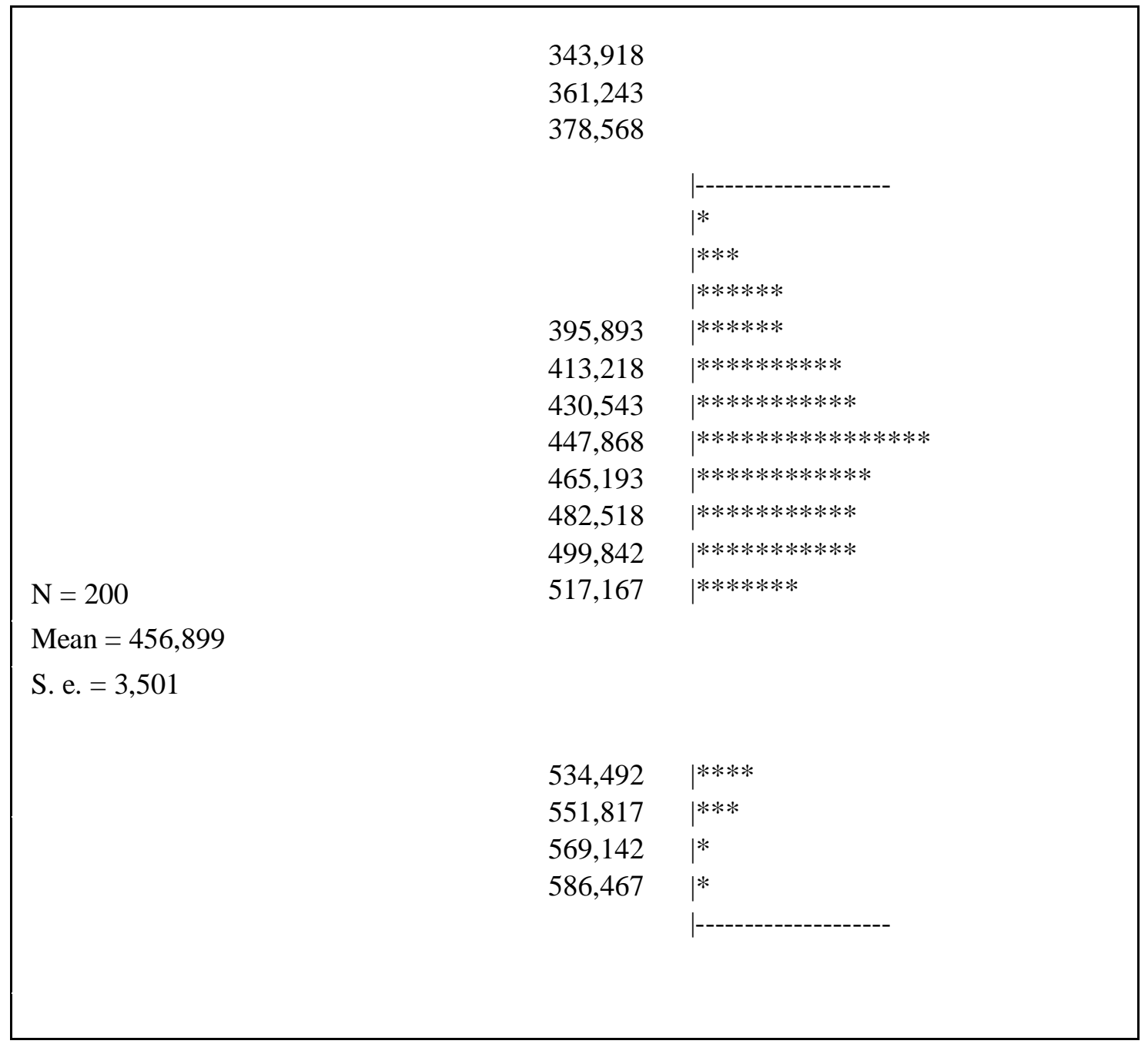

Figure 3. Bootstrap Distributions

After bootstrappingit can be seen that the curve forms a symmetrical bell pattern, indicating that the data of the bootstrap result is normal distribution. It can be concluded that the model has fulfilled normal multivariate assumptions and can be continued on the next analysis.

\section{Reliability Test}

Reliability is the consistency of a measurement, high reliability indicates that the indicators have a high consistency in measuring its latent construct (Haryono\& Wardoyo, 2013: 144). The minimum reliability value of an acceptable latent variable forming indicator is 0.70 . To obtain the value of the reliability level of the latent variable forming indicator used the formula: 
$\int$ ConstReliability $=$

$\left(\sum^{\text {StandardLoading })^{2}}+\sum^{\varepsilon j}\right.$

The results of data processing are shown in table 5 .

Table 5. Reliability Test

\begin{tabular}{|l|r|}
\hline \multicolumn{1}{|c|}{ Variable } & Reliability \\
\hline Performance appraisal & 0,760 \\
\hline Compensation & 0,793 \\
\hline Job Satisfaction & 0,784 \\
\hline Loyalty & 0,831 \\
\hline
\end{tabular}

The calculation results show that all reliability values are above 0.7 . This means that the measurement of the latent variable formator is acceptable and has already qualified for reliability.

\section{Hypothesis testing and Interpretation}

The next stage is testingthe research hypothesis. The test is conducted on 5 hypotheses that have been proposed. Regression value of data processing results can be seen in table 6 below:

Table 6. Regression

\begin{tabular}{|l|l|l|r|r|r|r|l|}
\hline & & & Estimate & S.E. & C.R. & P & Label \\
\hline JS & $<--$ & PA &, 369 &, 156 & 2,364 &, 018 & par_15 \\
\hline JS & $<--$ & CP &, 639 &, 158 & 4,036 & $* * *$ & par_16 \\
\hline Ly & $<--$ & JS &, 750 &, 173 & 4,321 & $* * *$ & par_17 \\
\hline
\end{tabular}

Based on table 6, all hypotheses proposed in this study can be discussed as follows:

$\mathrm{H}_{1}$ : Performance appraisal affects job satisfaction.

With a Critical Ratio (C.R.) $=2,364 \geq 1.967$ and probability $=0,018(\mathrm{p}<0,05)$, it can be concluded that the performance appraisal has a positive effect on job satisfaction.

The results of this study support previous researches conducted by Malik and Hussain (2011); Ahmed et al. (2010); January et al. (2015) and Ibeogu and Ozturen (2015) where the results of this study also prove that there is a relationship between performance appraisal and job satisfaction. Similar to the results of the study from Darehzereshki (2013), it is revealed that there is a relatively strong relationship between high-quality performance appraisal and job satisfaction, this study shows that that a performance appraisal process which result in low assessment level will negatively affect job satisfaction. In the contrary, a high and objective assessment will positively result in a high job satisfaction.

Performance appraisal is a basic component of human resource management, assessment results can be used as the basis of many HR decisions. The results of this study are also supported by Hasibuan's opinion (2014: 88) that the reason for performing performance appraisal is to increase employee satisfaction level by giving recognition to their work result.

$\mathrm{H}_{2}$ : Compensation affects job satisfaction 
With a Critical Ratio (C.R.) $=4.036 \geq 1.967$ and with probability $=0,000(p>0,05)$, it can be concluded that the compensation has a positive effect on job satisfaction.

The results of this study supporta research conducted by Salisu, Chinyio and Suresh (2015). It is also similarity shown in researches of Gelard and Rezaei (2016); Queiri et al. (2015) and Daud (2016) where it is concluded that there is an effect of the size of the compensation received with the level of job satisfaction of employees in the place of work. It is also similar to Ngirande's (2014) research, it is critical for management to develop strategies that address employee compensation and job satisfaction as a major factor; this means that management must be able to create a total reward structure that includes more than compensation.

The compensation received must be profitable in order to attract valuable employees to remain in the company. This is in line with the opinions of Rivai and Sagala (2013: 858), in the work of satisfaction one of which may refer to the compensation given by the entrepreneur, the individual will be satisfied if one experiences things like results or rewards that can be more than expected, the results achieved greater than the standard set and if the obtained by the employee in accordance with the requested conditions.

\section{$\mathrm{H}_{3}$ : Job satisfaction affects loyalty}

With a Critical Ratio (C.R.) $=4.321 \geq 1.967$ and with probability $=0,000(\mathrm{p}<0.05)$, it can be concluded that there is a positive correlation between job satisfaction with loyalty.

The results of this study support the previous researches by Waqas et al. (2014); Pandey and Khare (2012) as well as Javed et al. (2014) proving that there is an influence between job satisfaction in shaping the Y-generation work loyalty in the workplace. Based on the results of research Singh et el. (2011), Most employees easily agree to the concept that they can easily resign from their current employment once being offered a more promising package. Therefore, the general goal is to obtain job satisfaction.

An increase in employees' satisfaction will make them more committed and loyal to their organization. This is also in line with the opinion of McShane and Glinow (2009: 108) which states that those who are satisfied with their work will be more productive, creative and committed to companies in which organizations with more satisfied employees tend to be more effective than organizations with fewer satisfied employees.

It can be concluded from the results of research that satisfaction of salary, valued work and opportunity to be promoted to measure how much employees enjoy his job and is the attitude of employees related to the psychological condition, where if employees feel fulfilled the level of job satisfaction there is a tendency will be more loyal to the organization where he works now.

To test $\mathrm{H}_{4}$ and $\mathrm{H}_{5}$, then the calculation used Sobel Test. The calculation results can be seen in table 7 below:

Table 7. Sobel Test

\begin{tabular}{|l|l|l|l|}
\hline Hypothesis & Path & Sobel Test & probability \\
\hline H4 & $\begin{array}{l}\text { Performance appraisal } \rightarrow \text { Job } \\
\text { satisfaction } \rightarrow \text { Loyalty }\end{array}$ & 2,076 & 0,038 \\
\hline H5 & $\begin{array}{l}\text { Compensation } \rightarrow \text { Job satisfaction } \\
\rightarrow \text { Loyalty }\end{array}$ & 2,957 & 0,003 \\
\hline
\end{tabular}

$\mathrm{H}_{4}$ : Performance appraisal affects loyalty through job satisfaction.

The result of calculation of Sobel Test value is $2,076 \geq 1,967$ with probability $=0,038(p<0,05)$.

Thus hypothesis 4 accepted because there is a positive correlation between performance appraisal through job satisfaction in shaping employee loyalty work.

The results of this study are in line with Johari et al. (2012); Brown and Heywood

(2005) and Othman and Lembang (2017), that there is the effect of performance evaluation that can be done justly to form the work satisfaction of generation Y so as to generate Y generation's 
desire to stay at the organization where they work. In accordance with the opinion of Handoko (2014: 135), performance appraisal is the process by which the organization evaluates employee performance, this activity can improve personnel decisions and provide feedback to employees about the implementation of their work.

Handoko (2014: 196) argues thatemployees who get job satisfaction usually have a better attendance and regulatory record, but are less active in union activities and usually perform better than employees who do not get job satisfaction. Can be said by the fulfillment of high employee performance of course along with the high performance appraisal also, it is certainly influential with the high job satisfaction perceived by employees. So the creation of high job satisfaction will be accompanied by more loyalty to the organization where the Y generation works.

\section{$\mathrm{H}_{5}$ : Compensationaffects loyalty through job satisfaction}

The result of calculation of Sobel Test value is $2,957 \geq 1,967$ with probability $=0,003(\mathrm{p}<0,05)$. Thus hypothesis 5 is accepted because there is a positive correlation between compensation through job satisfaction in shaping employee loyalty. The results of this study support researches by Milman and Ricci (2004); Ibrahim et al. (2015) and David (2015), proving that appropriate compensation can create job satisfaction that can make Y generation to stay longer in their current organization.

The results of Paul and Sharma (2016) recommend that the benefits of compensation will increase employee job satisfaction which in turn will make employees more committed and loyal to their company.

According to Sinha and Sinha (2012), offering high compensation is expected to increase the loyalty of generation $\mathrm{Y}$ employees because of job satisfaction in a form of benefits received. Compensation is only able to attract employees at an early stage but is unable to retain $\mathrm{Y}$ generation in generals. At some point, compensation can not guarantee the loyalty of the Y generation because at some point they will have the intention of leaving the company. Thus, the company must be more creative in handling the Y generation loyalty.

\section{Analysis of Direct Effect, Indirect Effect, and Total Effect}

The calculation results are shown in table 8 .

Table 8. Direct Effects

\begin{tabular}{|c|c|c|c|c|}
\hline & CP & PA & JS & LY \\
\hline JS &, 639 &, 369 &, 000 &, 000 \\
\hline LY &, 000 &, 000 &, 750 &, 000 \\
\hline
\end{tabular}

In this study there are two variables that have a direct influence on job satisfaction variables and one variable that has a direct influence on work loyalty variables. The result of measurement shows that performance appraisal has an effect on job satisfaction with a coefficient of 0.369 and compensation has a direct effect on job satisfaction with a coefficient of 0,639 and job satisfaction has a direct effect on work loyalty with a coefficient of 0,750 .

The indirect effect is the effect that arises through an intermediate variable. The calculation results are shown in table 9.

Table 9. Indirect Effects

\begin{tabular}{|l|l|l|l|l|}
\hline & CP & PA & JS & LY \\
\hline LY &, 479 &, 277 &, 000 &, 000 \\
\hline
\end{tabular}

This research model also measured indirect influence between variables. There are two variables that have indirect effect to work loyalty. Performance appraisal has an indirect effect on work loyalty with a coefficient of 0.277 and compensation has an indirect effect on work loyalty with a 
coefficient of 0.479.Because of the direct influence and indirect influence between variables and models of this study, it is necessary to measure the total effect.

The total effect is the effect of the overall variable relationship.The calculation results are shown in table 10

Table 10. Total Effects

\begin{tabular}{|l|r|r|r|r|}
\hline & CP & PA & JS & LY \\
\hline JS &, 639 &, 369 &, 000 &, 000 \\
\hline LY &, 479 &, 277 &, 750 &, 000 \\
\hline
\end{tabular}

Table 10 above shows the impact of the relationship between constructs as a whole. It is very useful for companies to identify the focus factors of the company when dealing with employees behavior in order to improve loyalty and can also help identify factors to enhance company performance.

As seen in table 10,it is known that the variable that have the greatest impact to increase employee loyalty generation $\mathrm{Y}$ is the job satisfaction of 0.750 . Whereas the most efficient variable to improve job satisfaction is compensation; an increased compensation will be followed by an increased level of work satisfaction of generation Y employees.

Analysis of influence is intended to see how strong the influence of a variable on other variables either directly, or indirectly. Interpretation of these results will have significance to determine a clear strategy in improving job loyalty of generation Y. The calculation of direct, indirect, or total influence between exogenous variables on endogenous variables in this study was conducted to find right variables to improve work loyalty of generation $Y$ for more optimized results.

\section{CONCLUSION}

The results show that compensation greatly affects generation Y employees' job satisfaction by $0.64 \%$. Whereas performance appraisal at $0.37 \%$ has a lesser effect on employees' job satisfaction.Job satisfaction affects work loyalty of generation $\mathrm{Y}$ at $0.75 \%$, while the rest of $.25 \%$ are influenced by other variables outside of job satisfaction.

\section{BIBLIOGRAPHY}

Ahmed, A., Hussain, I., Ahmed, S., \& Akbar, M. F. (2010). Performance Appraisals Impact on Attitudinal Outcomes and Organizational Performance. Business and Management, 5 (10), 62-68.

Central Bureau of Statistics (2013). Projected Population Indonesia 2010-2035. https://www.bps.go.id/Demographic Bonus (2017)

https://kompas.id/baca/gaya-hidup/2017/02/12/bonus-demografi-si-doyanpindah/

Brown, M., Haytt, D., \& Benson, J. (2010). Consequences of the performance appraisal experience. British Journal of Industrial Relations, 39, 375-396.

Brown, M., Heywood, J.S. (2005). Performance appraisal systems: Determinants and change. British Journal of Industrial Relations, 43, 659-679.

Bruvik, K., \& Gibson, J.W. (2010). Reflection on Executive Compensation. Allied Academies International Internet Conference, 12, 133-138.

Buckley, P., Viechnickl, P. \&Barua, A. (2015). A new understanding of Millennials: Generational differences re-examined, Deloitte University Press.

Cummings, T.G., \& Worley, C. G. (2005). Organization development and change, (8th edition) Mason: Thomson South-Western. 
David, N. (2015). Determinants of Job Satisfaction: How Satisfied is the New Generation Employees in Malaysia,Social and Behavioral Sciences, 3, 208-213.

Deal, J. J. (2007). Retiring the generation gap: How employees young and old van and common ground. San Francisco: Jossey-Bass. ISBN: 0787985252

Dessler, G. (2013). Human Resource Management (13th edition). Upper Saddle River: PrenticeHall.

Encyclopedia Britannica. (1998). The Definition of Loyalty.http: //www.web2010.com.marceric/archive/arc3.htm

Garcia, B. J., Gargallo, C. A., Marzo, N. M., \& Rivera, T. P. (2005). Job satisfaction: empirical evidence of gender differences, Women in management review, 20 (4), 279-288.

Gelard, P., \&Rezaei, S. (2016). The Relationship between Job Motivation, Compensation Satisfaction and Job Satisfaction in Employees of Tax Administration - A Case Study in Tehran. Social Science, 12 (2), 165-171.

Hair et al. (2006). Multivariate Data Analysis (6th edition). Upper Saddle River, New Jersey: Prantice-Hall.

Handoko, T. H. (2014). Personnel \& Human Resource Management. Yogyakarta: BPFE.

Haryono, S., \&Wardoyo, P. (2013). Structural Equation Modeling For Management Research Using AMOS 18.00. West Java: PT. Intermedia Personnel Utama.

Hasibuan, M. (2014). Human Resource Management, Jakarta: PT. Earth Script.

Hermawan, Asep (2009). Quantitative Paradigma Business Research. Jakarta: PT. Grasindo.

Ibeogu, P. H., \&Ozturen, A. (2015). Perception of Justice in Performance Appraisal and Effect on Satisfaction: Empirical Findings from Northern Cyprus Banks. Economics and Finance, 23, 964-969.

Ibrahim, Z., Ismail, A., Mohamed, N, A., Mohd, N, S. (2015). Association of Managers'Political Interests towards Employees Feelings of Distributive Justice and Job Satisfaction in Performance Appraisal System. Social and Behavioral Sciences, 6, 523-530.

January, C. I., Utami, H. N., \&Ruhana, I. (2015). Influence Performance Assessment on Job Satisfaction and Job Performance. Business Administration, 24 (2), 1-4.

Javed, M., Balouch, R., \& Hassan, F. (2014). Determinants of Job Satisfaction and its

Impact on Employee Performance and Turnover Intentions. Learning \&

Development, 4 (2), 120-140.

Johari, J., Yean, T.F., Adnan, Z. (2012). Promoting employee intention to stay. International Journal of Economics and Management, 6 (2), 396-416.

Queiri, A., Fadzilah, W., Dwaikat, N. (2015). Explaining Generation-Y Employees' Turnover in Malaysian Context. Social Science, 11 (10), 126-138.

Queiri, A., Yusoff, W., Fadzilah, W. (2015). Generation-Y Employees' Turnover. Business and Management, 9 (11), 199-213.

Lai, H. (2012). A Study of the Relationship among the CompensationManagement, Operational and Organizational Climate. Organisatonal Innovation, 5, 231-249.

Malik, M. I., Hussain, S. (2011). Examining the Relationship of Performance Appraisal System and Employee Satisfaction. Business and Social Science, 2 (22), 243-247.

Masud, fuad (2004). Organizational Diagnostic Survey Concept \& Application, Diponegoro University Publishing Agency. 
McCrindle, M. (2006). New Generations at Wor. Social Researcher, available at www.mccrindle.com.au

McShane, S., Glinow, V. (2009). Organizational Behavior, emerging knowledge and practice for the real world.NewYork: Mc Graw-Hill 5th edition.

Milman, A., Ricci, P. (2004). Predicting job retention of hourly employees in the lodging industry. Journal of Hospitality and Tourism Management, 11, 23-41.

Othman, S, Z., Lembang, S. (2017). What is Gen Y to Stay in Organization? HR Practices, Organizational Support or Leadership Style. Management and Marketing, 7 (2), 1-9.

Pandey, C., \&Khare, R. (2012). Impact of Job Satisfaction and Organizational Commitment of Employee Loyalty, Social Science \& Interdisciplinary Research, 1 (8), 26-41.

Powers, E. L. (2000) Employee Loyalty in the New Millennium. S.A.M. Advanced Management Journal, 65 (3), 4-8

PwC survey (2011). Millennials at work, Reshaping the workplace. www.pwc.com, 1-28.

Raziq, A., \&Maulabakhsh, R. (2015). Impact of Working Environment on Job Satisfaction. Economics and Finance, 23, 717-725.

Rivai, V., \&Sagala, E. J. (2013). Human Resource Management for the Company. Jakarta: PT. Raja GrafindoPersada.

Robbins, S. P., \& Judge, T. A. (2009). Organizational behavior, 13th Edition. New Jersey: Pearson Education, Inc.

Santoso, Singgih (2015). AMOS 22 for Structural Equation Modeling Basic Concepts and Applications. Jakarta: PT. Elex Media Komputindo.

Salisu, B. J., Chinyio, E., \& Suresh, S. (2015). The impact of compensation on the job satisfaction of public sector construction workers of jigawa state of Nigeria. Business and Management, $6(4), 282-296$.

Sedarmayanti (2015). Human Resource Management, Bureaucratic Reform and Civil Servant Management. Bandung: PT. RefikaAditama.

Smola, K.W. \& Sutton, C.D. (2002). Generational differences: revisiting generational work values for the new millennium. Journal of organizational behavior. 23, 363382.

Solnet, D., \& Hood, A. (2012). Generation-Y as Hospitality Employees: Framing a Research Agenda. Hospitality and Tourism Management, 15, 59-68.

Steensma, H., \&Visser, E. (2007). Procedural justice and supervisors 'personal power bases: effects on employees' perceptions of performance appraisal sessions, commitment, and motivation. Collective Negotiations, 31, 101-118.

Sutrisno, Edy (2014). Human Resource Management. Jakarta: Kencana

Twenge, J., Campbel, S., Hoffman, B., \& Lance, C. (2010). Generational Differences in Work Values: Leisure and Extrinsic Values Increasing, Social and Intrinsic Values Decreasing. management, 36 (5), 1117-1142.

Waqas, A., Bashir, U., Sattar, M. F., Abdullah, H. M., \& Arshad, R. (2014). Factors Influencing Job Satisfaction and Its Impact on Job Loyalty. Learning \& Development, 4 (2), 141-161. 